\title{
Prevent Breeding Of Mosquitoes
}

Call Rentokil for advice \& solutions on how to get rid of mosquitoes on your properties.

\section{Marketing Intelligence and Planning}

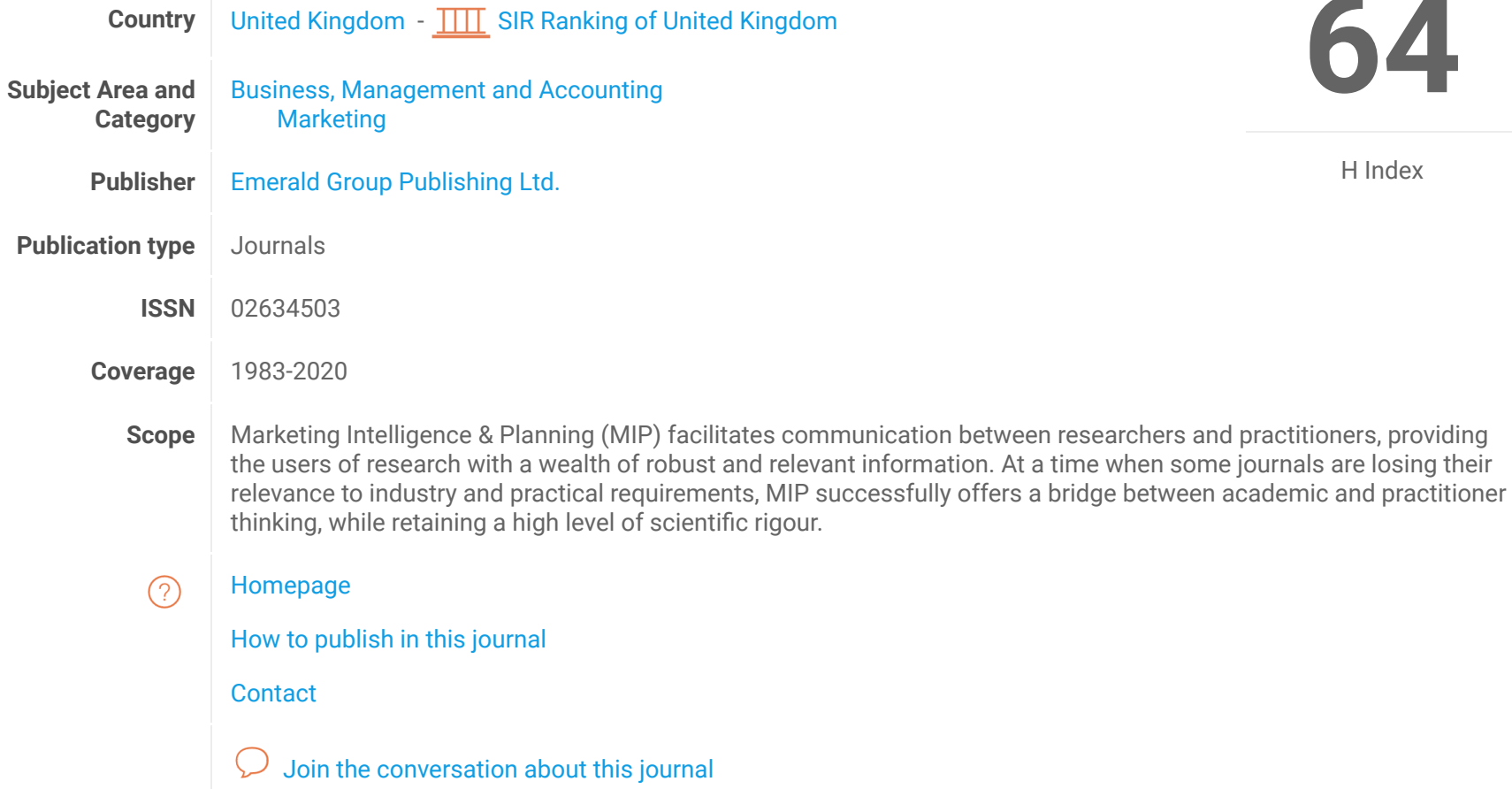

Scope Marketing Intelligence \& Planning (MIP) facilitates communication between researchers and practitioners, providing the users of research with a wealth of robust and relevant information. At a time when some journals are losing their relevance to industry and practical requirements, MIP successfully offers a bridge between academic and practitioner thinking, while retaining a high level of scientific rigour.

(?) Homepage

How to publish in this journal

Contact

Join the conversation about this journal

\section{Free Grammar Checker}

Eliminate grammar errors instantly and enhance your writing with Grammarly 

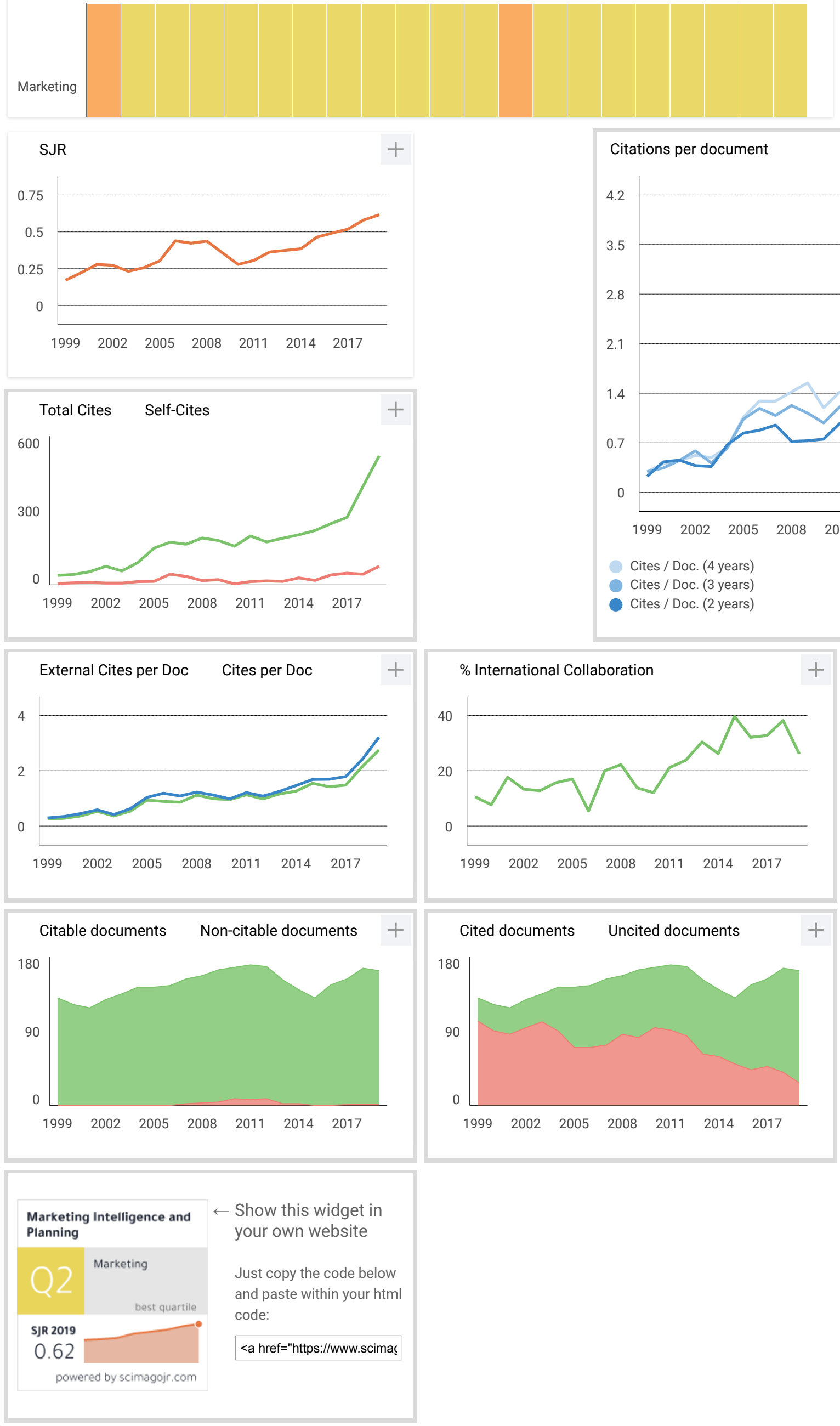


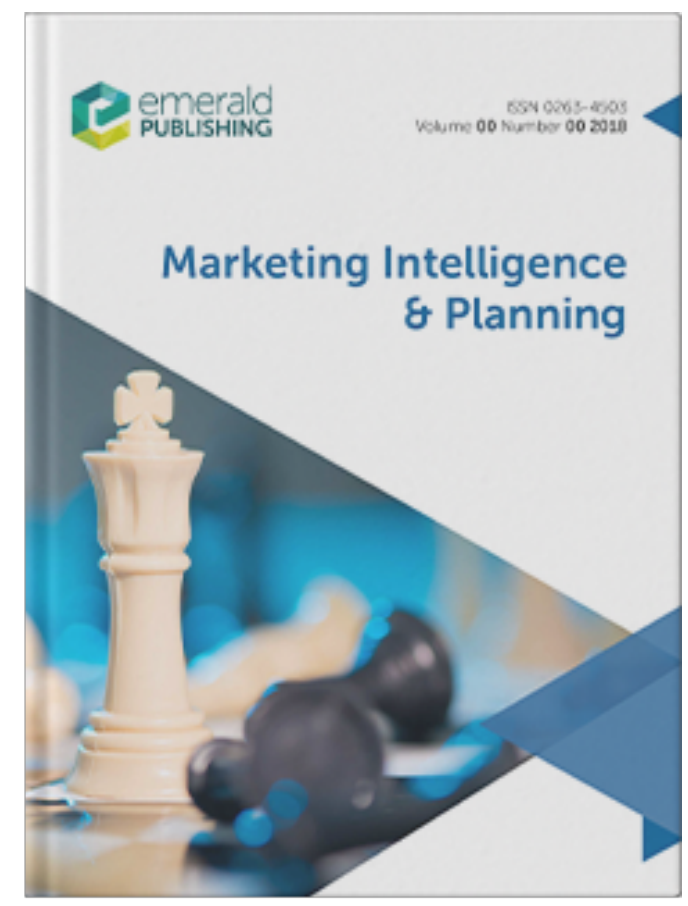

\section{Marketing Intelligence \& Planning}

ISSN: 0263-4503

\section{Submit your paper}

Useful links:

Table of contents

Get a sample article

How to subscribe $\&$ buy

\section{Journal description}

Marketing Intelligence \& Planning (MIP) facilitates

communication between researchers and

practitioners, providing the users of research with a 
wealth of robust and relevant information.

\section{Aims \& scope}

At a time when some journals are losing their relevance to industry and practical requirements, MIP successfully offers a bridge between academic and practitioner thinking, while retaining a high level of scientific rigour.

By analysing the relationship between the planning and implementation stages, the journal offers practical advantages to marketers aiming to sharpen their skills and give new impetus to marketing campaigns. Both academics and practitioners will gain from the wide perspectives on all stages of the marketing process.

"I have been on the Advisory Board of Marketing Intelligence and Planning for many years. I am also on the Advisory Boards of many other academic journals. I have seen the "scientific" quality of most journals increase over the years, but alas at the cost of managerial relevance. MIP, on the other hand, whilst also raising the

\section{On this page}

Journal description

Aims \& scope

Editorial team

Author guidelines

Indexing \& rankings

Related journals 
scientific quality of its published papers,

has not sacrificed relevance and I would

We are using cookies to give you the best

experience on our website, but you are free to

manage these at any time. To continue with our

standard settings click "Accept". To find out more

Accept all cookies

and manage your cookies, click "Manage cookies"

\section{Manage cookies}

highly rated by me and in my opinion is

due for a significant upgrade by bodies

that formally review journal rankings."

- Professor Malcolm McDonald

\section{Editorial team}

\section{Editor}

Associate Professor Thomas Brashear-Alejandro University of Massachusetts at Amherst - USA

brashear@isenberg.umass.edu

\section{Founding Editor}

Professor Gordon R. Foxall FAcSS DSocSc FBPsS

FBAM

UK

Emeritus Professor Michael J. Thomas OBE (1933-

2010)

University of Strathclyde - UK

\section{Publisher}

Richard Whitfield

rwhitfieldaemerald.com

\section{Journal Editorial Office (For queries related to pre-acceptance)}


Jagdish Rana

Emerald Publishing

jagdish.emerald@cenveo.com

\section{Advisory Board}

Professor Andrew Alexander

University of Surrey - UK

Professor Michael D. J. Antioco

EDHEC Business School - France

Professor Barry J. Babin

Louisiana Technical University - USA

Professor Gloria Barczak

Northeastern University - USA

Professor Michael Basil

University of Lethbridge - Canada

Professor Russell W. Belk

Schulich School of Business, York University -

Canada

Professor Michael B. Beverland

University of Bath - UK

Professor David Boje

New Mexico State University - USA

Professor Stephen Brown

University of Ulster - UK

Professor George Christodoulides

American University of Sharjah - United Arab

Emirates

Professor Lynne Eagle

James Cook University - Australia

Professor Matthias Fifka

University Erlangen-Nürnberg - Germany

Professor Adam Finn

University of Alberta - Canada

Professor Gordon R. Foxall

Cardiff Business School - UK

Professor David B. Grant

Hanken School of Economics, Finland - Finland

Professor Evert Gummesson

Stockholm University - Sweden

Professor Chris Hackley

Royal Holloway University of London - UK

Professor Robert L. Heath Profesor in Communication University of Houston - USA

Professor Morris Holbrook

Columbia University - USA 
Professor Wesley J. Johnston

Georgia State University - USA

Professor Ajay K. Kohli

Georgia Institute of Technology - USA

Professor Shirley Leitch

Australian National University - Australia

Professor Roger Marshall

Auckland University of Technology - New Zealand

Professor Malcolm McDonald

Cranfield University - UK

Professor Phil Megicks

Plymouth University - UK

Professor Juliet Memery

Bournemouth University - UK

Professor Chezy Ofir

Hebrew University of Jerusalem - Israel

Professor Onno Omta

Wageningen University - Netherlands

Professor Adrian J. Palmer

ESC Rennes School of Business - France

Professor Andrew Parsons

Auckland University of Technology - New Zealand

Professor Jacqueline Pels

Universidad Torcuato Di Tella - Argentina

Professor Gerard Prendergast

Hong Kong Baptist University - Hong Kong

Professor Jon Reast

Bradford University - UK

Professor Amrik Sohal

Monash University - Australia

Professor Valérie Swaen

Université catholique de Louvain - Belgium

Professor Christoph Teller

University of Surrey - UK

Professor Caroline Tynan

Nottingham University Business School - UK

Professor Duane Windsor

Rice University - USA

Professor Gillian H. Wright

Manchester Metropolitan Business School - UK 


\section{Author guidelines}

\section{Indexing \& rankings}

Autographics; Business Source; Cabell's Directory of Publishing Opportunities in Management and Marketing; Collectanea Corporate; CPI Digest; Current Citations Express; Electronic Collections Online; Emerald Management Reviews; EP Collection; Expanded Academic Index; Galileo; General Reference Center; Innovative; Manning \& Napier; Market Research Abstracts; PsycINFO; ReadCube Discover; Scopus; Telebase; The Marketing Report; Zetoc (British Library); AIDEA (Italy); Australian Business Deans Council (ABDC) Journal Quality List - A ranking; Chartered Association of Business Schools (CABS, UK) Academic Journal Guide; QUALIS; Scopus; Social Science Citation Index SSCI (Clarivate Anaytics); The Publication Forum (Finland).

\section{Scopus}

Citescore 2019 


\section{Scopus}

CiteScore Tracker 2020

(updated monthly)

\section{Clarivate}

Analytics

2019 Impact Factor 
COVID-19: information on accessing the platform off-site here.

Welcome Guest user

\section{Marketing Intelligence \& Planning:}

\section{Volume 35 Issue 5}

Category: Marketing

Subscribe to Table of Content Alerts

\section{$\square)$}

\section{Table Of Contents}

$\underline{\text { Consumer responses to covert advertising in social media }}$

Fabian Göbel, Anton Meyer, B. Ramaseshan, $\underline{\text { Silke Bartsch }}$

The purpose of this paper is to contribute to marketing communications literature by exploring consumer responses to covert advertising (CA) in a social media context.

Acceptance and forwarding of electronic word of mouth

Sabita Mahapatra, Abhishek Mishra

The purpose of this paper is to examine the influence of source credibility, message credibility and tie strength, on acceptance and subsequent forwarding of electronic...

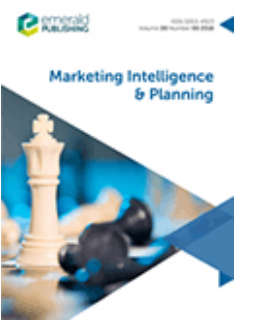

ISSN:

Anternational

standard

Serial

1983

Copyright Holder:

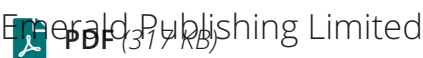

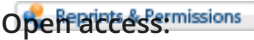

hybrid

Merged from:

Journal of Marketing

Practice: Applied

Marketing Science

Editor:

- Associate Professor

s TPBrmass Brashear

Alejandro

o. Reprints \& Permissions

Further Information

- About the Journal

- Purchase Information

- Editorial Team 日

- Write for this journal 
Comparing alternative approaches to estimate customer equity

Cleo Schmitt Silveira, Marta Olivia Rovedder de Oliveira, Fernando Bins Luce

The purpose of this paper is to explore the differences and similarities between two methods/models for estimating customer equity (CE): one using behavior-based data and...

\section{An enactment theory_perspective of corporate social responsibility and public relations} Gregoria Arum Yudarwati, Fandy Tjiptono

The purpose of this paper is threefold: how companies perceive corporate social responsibility (CSR) and public relations (PR); how companies perceive the interconnection...

Collective job crafting and team service recovery_performance: a moderated mediation mechanism

\section{Tuan Trong Luu}

The clinical team's recovery performance for the failures in the patient care processes plays a crucial role in leveraging the healthcare service quality. The purpose of...

Investigating the online customer experience - a B2B perspective

\section{GraemeJ. McLean}

This paper explores the online customer experience (OCE) within business-to-business (B2B) websites. The purpose of this paper is to understand the influence of website...

Uniqueness and status consumption in Generation Y consumers: Does moderation exist? Luke Butcher, Ian Phau, Anwar Sadat Shimul

The purpose of this paper is to explore the existence of consumers' need for uniqueness (CNFU) and status consumption (SC) in Generation Y (Gen Y). In exploring such, the...
\& PDF (158 KB) 
Crafting experiential value via smartphone apps channel

Sajad Rezaei, Naser Valaei

The purpose of this paper is to investigate the impact of post-usage usefulness (PUU), experiential value, and apps channel satisfaction on consumer continuance intention...

Services
Authors
Editors
Librarians
Researchers
Reviewers

\section{About}

About Emerald

Working for Emerald

Contact us

Publication Sitemap y $f$ in

(c) 2020 Emerald Publishing

Limited

\section{Reviewers}

Policies and

information

Privacy notice

Site policies

Modern Slavery Act

Chair of Trustees governance statement

COVID-19 policy 


\title{
An enactment theory perspective of corporate social responsibility and public relations
}

\begin{abstract}
Purpose - This study aims to explore (1) how companies perceive CSR (Corporate Social Responsibility) and PR (Public Relations); (2) how companies perceive the interconnection between these functions; and (3) what factors contributing to their perceptions.

Methodology - An interpretive qualitative study was employed, where semi-structured interviews with thirty four members of PR and CSR departments and three top executives of three big mining (state-owned, private Indonesian, and multinational) companies in Indonesia were carried out. Archival data (e.g., newsletters, websites, and annual reports) were also utilized.
\end{abstract}

Findings - CSR and PR are perceived to be community relationship functions to gain and maintain organizational legitimacy from the communities and shareholders. Three factors shaping these functions: (1) the social and political changes in Indonesia; (2) the communities' collective culture; and (3) the nature of mining industry.

Research limitations/implications - The current study focused on how companies interpret and enact their interpretations of their organizational environment. This study suggests further research into how the community and other stakeholders interpret the company's activities and environment. This study also suggests further study on another type of industry.

Originality/value - The present study provides another approach to understanding how CSR and PR are constructed and enacted in an organization as well as to understanding the company's justification in enacting particular CSR and PR functions. This study maintains the need to consider local values while keeping the global standard.

Keywords - Corporate Social Responsibility, Public Relations, enactment theory, mining industry, community, Indonesia.

Paper type - research paper 


\section{Introduction}

Corporate Social Responsibility (CSR) is one of the hottest topics in management today (Skarmeas and Leonidou, 2013). More businesses realize the need to consider social, environmental, and ethical issues beyond what is required by law (Aguinis and Glavas, 2012; Kang et al., 2016). Research in the Western context suggests that CSR is related to PR (Public Relations) practices (Bowen, 2006; Kim and Reber, 2008). The PR function in ensuring an organization acts socially responsible is shaped by the perceptions of PR practitioners and top managers towards CSR practices and PR profession. As Kim and Reber (2008) pointed out, the CSR roles of PR vary across different PR professionals and organizations. How organizations identify issues they must address and the priority they give to them are factors that shape their PR and CSR practices (Maon et al., 2008). Therefore, the development and implementation of PR and CSR functions is dependent on managerial understanding and sense making of their organizational environment (Cramer et al., 2006).

Further, Martinson (2000) asserted that to support the CSR commitment of an organization, PR practitioners are often caught between the proverbial "rock and a hard place”. In making an ethical decision, PR practitioners have to satisfy the company, public interest, PR codes of ethics, and their personal values (Skinner et al., 2003). Such decision rests with perception about the organizational environment (Fitzpatrick and Gauthier, 2001).

These issues raise important questions about how and why organizations perceive their organizational environment in particular ways and how these perceptions influence the enactment of CSR and PR within these organizations. More specifically, the present study aims to explore (1) how companies perceive CSR and PR; (2) how companies perceive the interconnection between these two functions; and (3) what factors contributing to their perceptions. These research objectives were examined using the enactment theory (Weick, 1979, 2001, 2009). The theory tries to understand how people think and act as organizational 
members by explaining the connections between the activities of organizational members and the environment. Heath $(2001$, p. 32) noted that "all of what each organization —as well as of each market, audience, and public — does and says becomes meaningful because of interpretations that people place on those actions and statements". Thus, this theory was chosen as a framework in understanding how PR and CSR practitioners as well as top managers perceive their organizational environment and how their perceptions shape the enactment of CSR and PR functions.

The Indonesian mining industry was chosen as the research context for three main reasons. First, the current study adopts the enactment theory that maintains that CSR and PR practices result from the way the organizational members make sense of the environment. The social, political, cultural, and economic conditions of Indonesia provide a rich background to study CSR and PR practices.

Second, the Indonesian mining industry has long experienced a problematic situation in regards to implementing CSR and maintaining good relationships with the community. While mining industry is a significant player in the Indonesian economy (Winzenried and Adhitya, 2014), it has been accused of several human rights and worker rights violations as well as environmental problems (Kemp, 2001). Most of mining companies in Indonesia operate in remote and under developed areas with complex social, economic, and cultural issues. Yakovleva (2005) argued that CSR is very relevant to the mining industry, since it has been negatively perceived as one of the most damaging and dangerous industrial sectors.

Third, Indonesia represents a part of the world that is under-represented in the CSR and PR literature. Many scholars suggest the importance of cultural factors in understanding CSR (Chapple and Moon, 2005; Skarmeas and Leonidou, 2013) and PR (Grunig et al., 1995; Sriramesh and Vercic, 2009), but there is still a lack of study conducted in Asian countries. Therefore, conducting study in Indonesia enables an examination of how Asian cultural 
values link to CSR and PR construction.

\section{Literature Review}

Despite CSR seems to mean different things to different people and companies, Dahlsrud (2008) suggested that five dimensions were found in most CSR definitions: environmental, social, economic, stakeholder, and voluntariness. These dimensions are captured in Carroll's (1991, p. 283) definition, where "the social responsibility of business encompasses the economic, legal, ethical and discretionary (philanthropic) expectations that society has of organizations at a given point in time".

The discussion of CSR often brings up the debate about whom corporations have responsibilities towards. Shareholder approach maintains that corporations are not created by society but are owned privately by shareholders (Hasnas, 1998). Accordingly, it is the right of corporations to be responsible only to shareholders. This approach has been criticized by stakeholder theorists, who emphasize the obligation of corporations to take into account their stakeholders (Donaldson and Preston, 1995; Evan and Freeman, 1995). Marrewijk (2003, p.97) argued that "corporations operate by public consent (license to operate) in order to serve constructively the needs of society - to the satisfaction of society". Furthermore, the institutional theory of CSR suggests that corporations are more likely to behave in socially responsible ways when they face strong government regulation, industrial self-regulation, NGOs (nongovernmental organizations) and other independent organizations that monitor their behavior, and a normative institutional environment that encourages socially responsible behavior (Campbell, 2007).

In relation to organizational commitment to be socially responsible, $\mathrm{PR}$ is believed to play a significant role (Freeman, 2006; L'Etang, 2006), where it supports management to adapt and adjust with the public's movements and maintain mutual understanding through 
two-way communication process (Wilcox et al., 2003). PR is also often related to CSR reporting. This relates to the organizational disclosure about their CSR activities as a means to create CSR awareness among consumers (Pomering and Dolnicar, 2009), to enhance corporate image (Pomering, 2011), to fulfill the regulatory requirements (Bartlett et al., 2007), to gain public legitimacy (Bachmann and Ingenhoff, 2016; Heath and Palenchar, 2011), to strengthen stakeholders' advocacy behavior (Du, et al., 2010), as well as to communicate with stakeholders (Gill et al., 2008).

The role of PR in CSR activities has been studied with mixed insights. Early studies in the U.S. revealed that PR practitioners performed only a limited role in the development of corporate's codes of conduct, were not involved in ethical decision-making processes, including CSR, and were not assigned to handle ethical and legal issues (Fitzpatrick, 1996; Heath and Ryan, 1989). The more current studies, however, show a different trend, where PR practitioners played important roles as counselors on ethical decision-making (Bowen, 2006), including CSR programs (Kim and Reber, 2008). Changing PR role in CSR works can be attributed to the increasing pressures from various stakeholders on organizations to deal with and respond to societal issues arising from their activities (Pinkston and Carroll, 1996). These issues include labor issues (Egels-Zanden and Hyllman, 2007), human rights (PunchevaMichelotti et al., 2010), and institutional performance (Waddock et al., 2002).

What this review implies is that each organization develops its own meaning of CSR and PR, as well as its own way to implement these practices, based on their perception towards their environment. Using the enactment theory (Weick, 1979), the current study explores how and why organizations perceive their organizational environment in particular ways and how these perceptions shape their practices of CSR and PR within their organizations. Enactment is closely connected to ecological changes, where it is "the only process where the organism directly engages an external 'environment"' (Weick, 1979, p. 
130).

The enactment theory focuses on the organizing process that the organizations experience in their attempt to understand all information that bombards them on a daily basis. The aim of organizing is to reduce equivocality, which refers to information having two or more clear and reasonable meanings (Weick, 1979). This implies multiple choices from which organizational members need to choose. In the process, organizational members relate to each other through some common objects of concern (Taylor and Robichaud, 2004). It will determine a foundation of action and maintain the coordination of the organization's members in responding to their environment. The idea of this theory is that "action defines cognition, existence precedes essence, and attitudes are draped supportively around prior actions that are tough to undo" (Weick, 2009, p. 195). Although people naturally believe that their actions are based on their beliefs, Weick (1979, p. 194) argues that the opposite is frequently also true, that actions precede beliefs.

The basic theme of organizing is the idea: "How can I know what I think until I see what I say?" (Weick, 1979, p. 133). It is in line with the proposition that, "I'll see it when I believe it". Beliefs represent cause maps that people execute on the part of the world they enacted. This is also related to the concept of self-fulfilling prophecies, where people see what they expect to find (Heath and Bryant, 2000). Individuals tend to be active actors who shape their worlds. In the organizational context, the organizations create their own social reality by influencing the situation and the behaviors they observe in others. Therefore, enactment implies that taking actions produces cognitions, which then guide further actions (Marcus and Andersen 2013). In the present study, the enactment theory becomes a framework to understand how organizations enacted CSR and PR as the way to confirm what they believed. 


\section{Methodology}

The present study is a qualitative study based on an interpretive approach. To understand how and why a certain company adopts specific CSR and PR practices, this study employed a case study approach. Case study allows researchers to investigate a phenomenon within its real-life context since it is conducted in a natural setting where the process studied happens (Yin, 2009).

The present study employed the enactment theory which maintains that CSR and PR are results of the enactment process of organizational members towards their environment. Since the context in which an organization operates is important, a multiple case design was utilized. Three large mining companies representing three different ownership types (multinational, state-owned, and privately-owned corporations) were selected. Using a list of Indonesian mining companies provided by the Indonesian Mining Association, the selection of specific companies was based on four criteria. First, the company chosen must have an articulated CSR and PR policy. Second, the company must have a unit that is responsible for conducting CSR and PR activities. Third, in order to facilitate an understanding of social and political background of Indonesian mining industry, the company must start their operation during Suharto era and continue to operate until Post-Suharto era. Fourth, the company allowed the researchers to access the data within its organization.

The primary data for this study were collected through semi-structured interviews. Thirty seven informants participated in the interviews, representing two groups: members of top-level management who were directly responsible for the PR and CSR units; and members of units that were responsible for PR and CSR functions at the operational level. The interviews were carried out using an interview guide which contained a list of questions about participants' perceptions of CSR and PR as well as their interconnection and practices in their companies. 
Additional data sources were also collected and analyzed, such as newsletters, magazines, brochures, annual reports, code of ethics, and any other files of company activities. The internal official documents provide information about the companies' activities, internal rules and regulation, job description, as well as internal chain of command. Meanwhile, the official documents that were distributed for external publics, such as brochures, newsletters, and magazines, provide information on how companies position themselves in the public.

\section{Findings}

\section{How Companies Perceive CSR and PR}

It was evident from the interviews that the term "community development" was used interchangeably with CSR within mining companies. CSR has been interpreted in many ways, i.e., social license to operate, commitment, moral obligation, program, image building tool, and an integrated part of Good Corporate Governance. CSR is perceived to be crucial to reduce conflicts and to gain social acceptance and organizational legitimacy from the communities and stakeholders.

"CSR is a moral obligation of the company." [A-01]

"CSR reflects how companies care for their society." [A-02]

"CSR is a commitment in the form of community relations and community development. What for? We can get a license to operate. It is called social license to operate." [B-08]

"Despite the fact that CSR has been regulated by the government, this has also become a willingness of the company to perform it. This is in order to secure the company, to make sure that they can work without any disturbances." [A-04]

Unlike participants from the multinational and the Indonesian private company, the participants from the state-owned company also perceived CSR as a government directive program, i.e., "partnership and environmental development" program. Participant C-07, for 
instance, explained that every state-owned company was obliged to carry out such a program under the supervision of the State Minister for State-Owned Enterprises.

Meanwhile, PR was perceived as a communication tool to share information about companies and to build a favorable image among stakeholders. The three mining companies tend to focus on media relationships, especially with local newspapers and their journalists. For them, reputation management is the main priority since mining industry is considered a controversial business due to negative public perceptions toward its practices (Cai et al., 2012). PR was enacted by the three mining companies to communicate how their activities and concerns are in line with public expectations. It is essentially a symbolic management approach to gain public legitimacy and 'social license to operate'.

"PR is a communication tool to connect the company and its public, as well as plays a role in disseminating or monitoring recent issues in the society." [A-06]

"The objective of PR is to create a good image of the company." [C-01]

"In my view, PR is actually the 'spearhead' of company to inform about what is going on in the company. That's the first. Secondly, ... it can monitor activities in the community..." [C-03]

\section{Perceived CSR-PR Interconnections}

The beginning of PR practices in Indonesia can be traced to the period of 1945 to mid-1950s, where media relations and global diplomatic relationships were utilized to publicize Indonesia's independence internationally (Muntahar, 1985). However, the term 'public relations' was firstly introduced in Indonesia by multinational oil and mining corporations in the early 1950s. These companies used PR to convince both the Indonesian government and public about the opportunities they offered for a better living nation (Ananto, 2004). Until early 1970 s, the main focus of PR practices was to handle media publication.

During the same period (1945 to early 1970s), CSR as a concept was not an important issue for mining industry and other industries operating in Indonesia. The contract of work 
between the Indonesian government and foreign investors, for instance, did not include the social responsibility of the mining companies. Things have changed significantly since the end of Suharto era in 1998. Mining companies faced several CSR-related problems, such as labor, human rights, and environmental issues (Kemp, 2001). Ethical business and CSR practices have become an important concern in Indonesia, where the government issued several regulations to promote CSR practices (e.g., article 74(1) of Law No. 40/2007 which obliges companies in the natural resources related sectors to participate in environmental social responsibility).

The growth of CSR concerns has brought a positive effect on PR practices. During the Suharto era (1966-1998), PR practices were limited to the one-way communication process, focusing on creating favorable image and minimizing negative publicity (Ananto, 2004). In the post-Suharto era (after 1998), CSR has become one of the most important issues that PR practitioners manage. In relation to this, mining companies have started to set an independent unit to handle PR and CSR functions.

Our interview results reveal that CSR and PR were perceived to be interconnected. This is in line with previous studies, which imply the interconnection between both practices. Nevertheless, the current study found that the interconnection was perceived as a relationship function to mitigate risks due conflicts with communities, instead of something to do with business ethics or responsibility to manage the impact of companies to the society and environment. This study also revealed that ownership type shapes the perceptions. An educating role of PR was found only in the state-owned company. Specifically, five key roles were identified from the interviews. Two of them are integrated CSR and PR roles, while the other three are specific PR roles that support CSR functions (see Table 1).

\section{Factors Shaping Companies' CSR and PR Practices}


To understand the rationales behind the mining companies' CSR and PR practices, the participants were asked to explain what they believed as the factors influencing such practices. In their responses to these questions, the participants always referred to what they had experienced in the past. This suggests how interpretations focus only on elapsed events and what has happened. This also supports the premise of enactment theory that action precedes cognition.

Enactment is mostly triggered by ecological changes that the organization perceived as important to be managed. The participants suggested three influential factors in their enactment process: (1) the social and political changes in the post-Suharto era, (2) the communities' cultural values, and (3) the nature of the mining industry. The current research found that the way each company constructed and enacted each factor was influenced by their ownership types. The results of the enactment were enacted environments within which the companies' decisions and actions about CSR and PR practices were made.

\section{The social and political changes in the post-Suharto era}

Most participants mentioned the transition from the centralized system during the Suharto era to the decentralized and democratic system in the reformation (post-Suharto) era as a crucial factor influencing their current practices of CSR and PR in the mining industry.

"In the New Order (Suharto) era, the role of the military was very dominant." [B-03]

"For us, the security approach provided by the government in the New Order era made us secure." [A-02]

After Suharto's resignation in 1998, however, political changes have affected the relationships between the company and its stakeholders, especially local communities. Most participants noted that the reformation era led the community to demand their rights to speak and to be listened to, as well as to demand company's transparency. With greater community freedom, the number of social conflicts has increased. 
"Before 1998, the community never had a demonstration. But in the reformation era the conditions have changed." [C-06]

"Honestly... since 2000 the community's flame has been so tremendous." [C-01]

Further, the decentralization policy affects how mining companies respond to local government's needs. Local government has now become "little kings/queens" in their regions.

"The decentralized government in the post-Suharto era also affects the company, since most aspects of the industry are now under the jurisdiction of local government..... In the post-Suharto era, the company needs to build relationships with the local government." [B-01]

Conflicts of interest among the company, their communities, and local government were perceived by participants as destructive conditions for the company. The participants pointed out that the company had to develop a new strategy as they could not rely on military protection from the government anymore.

"The company has to allocate resources and develop strategies to handle social pressures and conflicts, which have tended to be uncontrollable." [C-03]

"The company has started to treat the communities and the local government as their main stakeholders." [A-01]

The present study found that these social and political changes in the post-Suharto era have urged companies to develop CSR and PR programs as their strategies to reduce conflicts with the community. The Indonesian private company and the multinational corporation established an independent division to manage CSR and PR programs at their mining sites and have allocated a significant number of people to support it.

"In 2003 the company established an independent division to manage external affairs and CSR programs" [A-02]

"We realized that we could not rely on the government and PR department to handle all problems. We need more departments to manage each stakeholder... There are 120 people within this division. Meanwhile, during the Suharto era, there were only two or three people handling external relations." [B-08] 
The state-owned company also established an independent unit, called Public Relations and Community Development Department, at its mining site. However, fewer staffs were employed for the department:

"We only have 4 staff under PR unit. I report to the Manager of PR and Community Development Department. Under this department, there are units of PR, Community Development, and Safety." [C-04]

\section{The communities' cultural values}

The present study revealed that local community's cultures (beliefs, traditions, rituals, language, and religion) have shaped the way mining companies conduct CSR and PR. There are four reasons why participants perceived community's cultures to be important. First, land acquisition often caused conflicts between the company and the communities due to the ownership status of the cultural land as well as the cultural value of the land itself. Second, there are dominant collectivistic values among the ethnic groups living around the mining area. Third, community members tended to speak in their ethnic languages rather than in Indonesian. Finally, religion plays a very important role in people's lives within the community. The following shows how these cultural factors affect the way mining companies enact their CSR and PR programs:

a. $\quad$ The Indonesian private firm and the multinational company assigned field officers who have the same cultural background as the community.

Field officers are mainly responsible for assisting the community in performing community development programs. They were recruited from local people and lived in the community.

"I am a Bugis, they are also Bugis. We mostly communicate in Bugis language. We can communicate easily and closely. They treat me as their family." [A-11] 
Field officers have become front liners as well as eyes and ears of the companies, who assist them in solving problems with the community. They were usually involved in this matter since they have built strong relationships with communities.

"In a conflict management process, field officers play an important role in providing inputs, since they know better about the situation in the field." [A-14]

\section{b. Building informal and personal relationships with key actors}

All companies studied build informal and personal relationships with key actors. Employing mostly local people in community relation positions provide an advantage of building good rapport with key figures, such as ethic group leaders and local government officers.

"When there are conflicts involving members from different ethnic groups, kepala desa [village head] will not be able to do anything. The community will only listen to their ethnic group or adat leaders". [A-14]

"The company needs to build and maintain good relationships with them [local government officers] to avoid difficulty in managing legal issues and to build good collaboration." [B-08]

\section{3. $\quad$ The nature of the mining industry}

The following three aspects characterize the mining industry in general.

a. $\quad$ The nature of the mining industry is contentious.

Issues relating to noises, environmental pollution, or jealousy between mining employees and non-employees due to income differences, all have implications for the local community. Despite the industry provides huge income for people living in the mining areas, it is a 'very easy to hate' business sector.

"The public tend to talk about negative issues about mining rather than positive ones.... Mining is a very easy to hate industry." [C-01]

"Mining industry is often criticized by the external public because it exploits natural resources.... Even though legally we signed a contract with the government, we are perceived as robbers." [B-01] 
This factor has led to the strategic role of CSR as a social license to operate and the importance of PR as media relations and image building tools to communicate company's social responsibility programs.

b. Mineral resources mostly are located in remote and undeveloped areas, in which traditional and subsistence communities live.

The participants observed that there was a lack of infrastructure facilities as well as a lack of educational background among the community. Most of the community members are low-income earners who relied on farming. These conditions have contributed to the importance of community development programs as well as employment issues.

"In the first three years since the company initiated its operation, employment had become the main source of conflict between the company and the community. This includes demands from community members and local contractors to work with the company, as well as the problems of those who lost their source of income as farmers or hunters since the company changed their land into a mining area." [B-01]

c. Mining industry has greatly influenced the way the indigenous people live.

Mining companies have been criticized for changing the lifestyle of indigenous people. Therefore, a cultural approach is needed in implementing CSR and PR programs.

"With the conversion of forest for mining purposes, the indigenous community had to give up their previous cultivation activities and work for the mining industry with the hope of a better economic status or start another job." [A-09]

\section{Discussion}

\section{Theoretical Implications}

All organizations construct and enact their environment (Daft and Weick, 2001). However, how they do it depends on their organizational and environmental factors. The present study contributes to the literature by investigating how CSR and PR practices are influenced by the enactment process of the companies. Research examining internal institutional determinants (i.e., how an organization makes sense of CSR and PR) has been limited in the CSR and PR fields (Campbell, 2006; Basu and Palazzo, 2008). 
The findings show that CSR has been perceived differently by top management and CSR practitioners in the Indonesian mining industry. It is not surprising since CSR is a dynamic phenomenon (Carroll, 1999) and an umbrella term overlapped with some other business-society relationship concepts (Matten and Moon, 2008). More importantly, CSR movements are relatively new in Indonesia. Meanwhile, there seems to be a similar perception of PR as a communication tool for reputation management.

Furthermore, CSR and PR are perceived to be inseparable functions (relationship building, image creating, facilitating, information disseminating, and educating roles) to gain legitimacy from important stakeholders. Although this finding seems to be expected, it is important to note that CSR and PR functions in the context of mining industry in Indonesia are enacted as part of risk mitigation strategy (Zhao et al., 2014) rather than as corporate conscience (Bowen and Rawlins, 2007) to ensure companies fulfilling their ethical and social responsibilities.

The findings indicate that the participants perceived a new unsupportive and more hostile reality, as a result of social and political changes in the post-Suharto era. The participants noted that in the Suharto era, their operations mainly were dependent on the government's approval. Consequently, the government was recognized as their main legitimate stakeholder and local communities as secondary to the government. Therefore, the easiest way to seek legitimacy was by positioning the companies within a pre-existing institutional regime (Suchman, 1995), which was the Suharto's government. In other words, during that period, regulative pillar was the most important element of the dimensions of the institutions (Scott, 2014). What these companies did was aligning their activities with the government's expectations by supporting the government development programs.

However, the conditions were different as Indonesia entered a democratic system in the post-Suharto era. The "power" has shifted from the central government to the local 
government and the community. The company's legitimacy was not given, but needs to be negotiated with the community. Mining companies can either ignore these ecological changes, or construct a new environment and enact it. The findings suggest that the Indonesian private company and the multinational corporation chose to actively engage with the changes by constructing and enacting the environment in new ways. As maintained by enactment theory (Weick, 1979, 2009), to reduce uncertainties due to ecological changes, the participants not only interpreted the events, but also enacted them based on their interpretations. The first action that these two mining companies took, as noted by the participants, was shifting the focus of relationship management, from building relationships with the central government to sustaining a harmonious relationship with the community.

Furthermore, these two companies established an independent division and allocated human resources to manage CSR and PR activities at the mining site, close to the communities they need to engage with. This supports the proposition that enactment is about taking action to react to what is believed. These companies chose an indirect adjustment (Weick, 2009) by changing their organizational structure, which is in line with their perceptions of CSR and PR as interconnection functions.

A different approach was chosen by the state-owned company, which only passively engaged with these ecological changes. Even though this company established an independent department at the mining site, its main function is to support the government directive programs and only a small number of employees were assigned to work for the department. This company did not want to enact a new environment since the change from an authoritarian to a democratic system in the post-Suharto era did not cause any impacts on the company or did not lead to equivocality. Therefore, the CSR and PR activities remained the same.

It can be argued that ownership type contributes to different responses to the 
environmental changes. The Indonesian private company and the multinational corporation enacted the changes since they believed that their shareholders expected them to secure their investments from any disturbances and to keep the operations profitable. The enactment of CSR and PR aims to gain the legitimacy from shareholders. The participants believed that the CSR and PR enactment can reduce discrepancy between their companies' behaviors with shareholder's expectations. Legitimacy validates the organization's role in the society and assists the organization to invest other resources and gain continued support from the society, including shareholders (Ashforth and Gibbs, 1990). The Indonesian private company, which claims itself as an international player, and the multinational corporation comply with the international standards and the Indonesian government regulations. This finding lends support to Chappel and Moon (2005) who suggest that firms operating internationally are more likely to engage in CSR and to institutionalize it through codes.

Meanwhile, in the state-owned company, its main shareholder was the government, who controlled its operation through the Ministry of State Owned Enterprises. This company accordingly enacted the government regulations as part of their obligation. Such circumstance leads to a stereotypical enactment process, where enactment becomes a resemblance of standard operating procedures (SOP) within the organization. Organizational members act and interpret the enacted environment (the SOP) instead of the current business environment. They try to fit their interpretations and actions into what they have known all along and tend to remove or misread anything that does not fit. As a result, this company tends to be slow or even difficult to change in the new environment.

\section{Managerial Implications}

The present study found that cultural factors influence the way companies conducted CSR and PR practices. The participants enacted their collective culture by utilizing personal 
approaches in building relationships with the community. This finding is consistent with what Whelan (2007) argued: CSR is always embedded within specific social and cultural context. Local factors strongly affect priority issues and operational aspects of CSR and PR implementation (Sriramesh and Vercic, 2009; Weyzig, 2006).

To enact personal approaches with communities, the mining companies assigned field officers who were acting as CSR and PR officers of the company. Their role is to interpret what had happened in the community as well as to identify key actors within the community. The Indonesian private firm and the multinational company assigned more field officers compared to the state-owned company. As Wilensky (1967) remarked, the more the company is in conflict with its social environment, the more resources it allocates to intelligence functions and the more of those resources will be spent on the field officers, who play a role as an agent, contact person, or issue manager.

The field officers were either recruited from the community with the same cultural background or from outside the community but had a good understanding of cultural differences. This approach is crucial in gaining legitimacy in a collective and high-context culture, such as Indonesia (Hall, 1976). Ethic groups in Indonesia generally maintain unwritten and unspoken rituals and beliefs. In this situation, there is less to be said or written because most of the meaning is in the physical environment or already shared by insiders (Jandt, 2007). Field officers are more likely to be accepted as an insider or an 'in-group' member of the community, if they have the same cultural background and speak the same local language.

The mining companies assigned field officers as interlocutors (Hall, 1976), who interact with the community and at the same time represent the company. Hall (1976) suggested that when there is a conflict, high-context communities tend to respond better to an interlocutor to understand what is bothering them. Field officers are also expected to play 
another role as cultural interpreters to improve the company's sensitivity towards local values. This role is usually enacted by an organization that conducts business in another country and an organization in a single country that must work in a multicultural environment (Grunig et al., 1995). This enacted cultural interpreter role reflects the principle of the enactment process that organizations are active social systems that interpret information from the environment to reduce uncertainties (Daft and Weick, 2001).

\section{Concluding Remarks}

Using case study of three large mining companies in Indonesia, the present study revealed that CSR and PR practices are resulted from the enactment process of organizational members towards the ecological changes in the post-Suharto era. Enactment theory maintains that there are uncertainties within the environment that urge organizations to seek interpretations, which then underline their actions. Each organization actively or passively engages in their environment. Participants perceived the social and political changes in the post-Suharto era have made the community emerged as the most powerful stakeholder.

It may be argued that the community may not really hold power over the companies. However, enactment theory is not about searching for the right answer; instead, it is about finding reasonable actions based on what the organizational members believe (Weick, 2009). What matters most is what the organizational members think they face and how their perceptions are confirmed by the actions they take (Hatch and Cunliffe, 2013). In other words, it is about how actions tend to confirm their perceptions. Thinking and acting are not separate activities but are intertwined and operate through the mechanism of sensemaking (Maitlis and Christianson, 2014).

Since the current study focuses on the company's viewpoints, it might not provide a whole picture of the dynamics and complexity of CSR and PR practices in an emerging 
market like Indonesia. It is important for the organizations to understand how their perceptions result in particular practices. It is critical for the organization to develop selfreflective understandings of how one arrives at certain interpretations. The organizations also need to develop analytical skills and tools to draw multiple interpretations about their environment rather than rely on one single interpretation which may result in single-oriented practices.

Furthermore, our findings indicate that mining companies enacted CSR and PR as functions to build good relationships with the stakeholders to mitigate risks and gain social license to operate from them. Bachmann and Ingenhoff (2016) highlighted that CSR disclosures have a positive effect on corporate legitimacy. However, Morsing et al. (2008) warned that publics do "not appreciate" communicated CSR. In the context of Indonesia, Arli and Tjiptono (2014) found that CSR matters for Indonesian consumers, where legal and philanthropic responsibilities are perceived to be more important than economic and ethical responsibilities. These findings provide future research opportunities to investigate how general public, people living in surrounding areas, government, consumers, and nongovernmental organizations perceive the genuineness of mining companies' CSR and PR activities. It is also important to note that the findings of our case study of three mining companies in Indonesia may have limited generalizability (Eisenhardt, 1989). Therefore, future studies are suggested to explore how CSR and PR are interconnected in different industries and different cultural contexts.

\section{References}

Aguinis, H. and Glavas, A. (2012), "What we know and don't know about corporate social responsibility", Journal of Management, Vol. 38 No. 4, pp. 932-968.

Ananto, E.G. (2004), "The development of public relations in Indonesia", in Sriramesh, K. (Ed.), Public Relations in Asia, Thomson, Singapore, pp. 261-282.

Arli, D. and Tjiptono, F. (2014), "Does corporate social responsibility matter to consumers in Indonesia?”, Social Responsibility Journal, Vol. 10 No. 3, pp. 537-549. 
Ashforth, B.E. and Gibbs, B.W. (1990), "The double-edge of organizational legitimation", Organization Science, Vol. 1 No. 2, pp. 177-194.

Bachmann, P. and Ingenhoff, D. (2016), "Legitimacy through CSR disclosures? the advantage outweighs the disadvantages",. Public Relations Review, Vol. 42 No. 3, pp. 386-394.

Bartlett, J., Tywoniak, S. and Hatcher, C. (2007), "Public relations professional practice and the institutionalisation of CSR", Journal of Communication Management, Vol. 11 No. 4, pp. 281-299.

Basu, K. and Palazzo, G. (2008), "Corporate social responsibility: a process model of sensemaking", Academy of Management Review, Vol. 33 No. 1, pp. 122-136.

Bowen, S.A. (2006), "Ethics and public relations", available at: http://www.instituteforpr.org/essential_knowledge/detail/ethics_and_public_relat ions/ (accessed 1 June 2012).

Bowen, S.A. and Rawlins, B.L. (2007), "Corporate moral conscience”, in Heath, R.L. (Ed.), Encyclopedia of Public Relations, Sage, Thousand Oaks, pp. 205-209.

Cai, Y., Jo, H. and Pan, C. (2012), "Doing well while doing bad? CSR in controversial industry sectors," Journal of Business Ethics, Vol.108 No. 4, pp. 467-480.

Campbell, J.L. (2006), "Institutional analysis and the paradox of corporate social responsibility", American Behavioral Scientist, Vol. 49 No. 7, pp. 925-938.

Campbell, J.L. (2007), "Why would corporations behave in socially responsible ways? an institutional theory of corporate social responsibility", Academy of Management Review, Vol. 32 No. 3, pp. 946-967.

Carroll, A.B. (1991), "The pyramid of corporate social responsibility”, Business Horizons, Vol. 34 No. 4, pp. 39-48.

Carroll, A.B. (1999), "Corporate social responsibility: evolution of a definitional construct", Business and Society, Vol. 38 No. 3, pp. 268-295.

Chapple, W. and Moon, J. (2005), "Corporate social responsibility (CSR) in Asia", Business and Society, Vol. 44 No. 4, pp. 415-441.

Cramer, J., Heijden, A.D. and Jonke, J. (2006), "Corporate social responsibility: making sense through thinking and acting", Business Ethics: A European Review, Vol. 15 No. 4, pp. 380-389.

Daft, R.L. and Weick, K.E. (2001), "Toward a model of organizations as interpretation systems," Organizational Studies. Critical Perspectives on Business and Management, Vol. 3, pp. 869-888.

Dahlsrud, A. (2008), "How corporate social responsibility is defined", Corporate Social Responsibility \& Environmental Management, Vol. 15, pp. 1-3.

Donaldson, T. and Preston, L.E. (1995), "The stakeholder theory of the corporation", Academy of Management Review, Vol. 20 No. 1, pp. 65-91.

Egels-Zanden, N. and Hyllman, P. (2007), "Evaluating strategies for negotiating workers' rights in transnational corporations", Journal of Business Ethics, Vol. 76 No. 2, pp. 207223.

Eisenhardt, K.M. (1989), "Building theories from case study research", Academy of Management Review, Vol. 14 No. 4, pp. 532-550.

Evan, W.M. and Freeman, R.E. (1995), "A stakeholder theory of the modern corporation", in Hoffman, M. and Frederick, R. (Eds.), Business Ethics: Readings and Cases in Corporate Morality, 3rd ed. McGraw-Hill, New York, pp. 145-154.

Fitzpatrick, K. and Gauthier, C. (2001), "Toward a professional responsibility theory of public relations ethics", Journal of Mass Media Ethics, Vol. 16 No. 2/3, pp. 193-212.

Fitzpatrick, K.R. (1996), "The role of public relations in the institutionalization of ethics", Public Relations Review, Vol. 22 No. 3, pp. 249-258. 
Freeman, B. (2006), "Substance sells: alligning corporate reputation and corporate responsibility", Public Relations Quarterly, Vol. 51 No. 1, pp. 12-19.

Grunig, J.E., et al. (1995), "Models of public relations in an international setting", Journal of Public Relations Research, Vol. 7 No. 3, pp. 163-186.

Hall, E.T. (1976), Beyond Culture, Anchor Press, New York.

Hasnas, J. (1998), "The normative theories of business ethics", Business Ethics Quarterly, Vol. 8 No. 1, pp. 19-42.

Hatch, M.J. and Cunliffe, A.L. (2013), Organization Theory, Oxford University Press, Oxford.

Heath, R.L. (2001), "A rhetorical enactment rationale for public relations", in Heath, R.L. (Ed.) Handbook of Public Relations, Sage Publication, Thousand Oaks, pp. 31-50.

Heath, R.L. and Bryant, J. (2000), Human Communication Theory and Research, 2nd ed., Lawrence Erlbaum, Mahwah.

Heath, R.L. and Palenchar, M.J. (2011), "Corporate (social) responsibility and issues management", in Ihlen, O., et al. (Eds.), The Handbook of Communication and Corporate Social Responsibility, Wiley-Blackwell, West Sussex, pp. 316-337.

Heath, R.L. and Ryan, M. (1989), "Public relations' role in defining corporate social responsibility", Journal of Mass Media Ethics, Vol. 4 No. 1, pp. 21-38.

Jandt, F.E. (2007), An Introduction to Intercultural Communication, Sage, Thousand Oaks.

Kemp, M. (2001), Corporate Social Responsibility in Indonesia, United Nations Research Institute for Social Development.

Kim, S.-Y. and Reber, B.H. (2008), "Public relations' place in corporate social responsibility", Public Relations Review, Vol. 34 No. 4, pp. 337-342.

L'Etang, J. (2006), "Corporate social responsibility and public relations ethics", in L'etang, J. and Pieczka, M. (Eds.), Public Relations Critical Debates and Contemporary Practice, Lawrence Erlbaum, Mahwah, pp. 405-422.

Maitlis, S. and Christianson, M. (2014), "Sensemaking in organizations: taking stock and moving forward", The Academy of Management Annals, Vol. 8 No. 1, pp. 57-125.

Maon, F., Lindgreen, A. and Swaen, V. (2008), "Thinking of the organization as a system", Systems Research and Behavioral Science, Vol. 25 No. 3, pp. 413-426.

Marcus, A.A. and Anderson, M.H. (2013), "Commitment to an emerging organizational field: an enactment theory", Business \& Society, Vol. 52 No. 2, pp. 181-212.

Marrewijk, M.V. (2003), "Concepts and definitions of CSR and corporate sustainability", Journal of Business Ethics, Vol. 44 No. 2, pp. 95-103.

Martinson, D. L. (2000), "Ethical decision making in public relations", Public Relations Quarterly, Vol. 45 No. 3, pp. 18-21.

Matten, D. and Moon, J. (2008), “"Implicit" and "explicit” CSR: a conceptual framework for a comparative understanding of corporate social responsibility", Academy of Management Review, Vol. 33 No. 2, pp. 404-424.

Morsing, M., Schultz, M. and Nielsen, K.U. (2008), "The 'Catch 22'of communicating CSR", Journal of Marketing Communications, Vol. 14 No. 2, pp. 97-111.

Muntahar, R.S. (1985), Hubungan Masyarakat, Andi Offset, Yogyakarta.

Pinkston, T.S. and Carroll, A.B. (1996), "A retrospective examination of CSR orientation: have they changed?", Journal of Business Ethics, Vol. 15 No. 2, pp. 199-206.

Pomering, A.A. (2011), "Communicating corporate social responsibility through corporate image advertising", in Ihlen, Ø., et al. (Eds.), The Handbook of Communication and Corporate Social Responsibility, Wiley-Blackwell, West Sussex, pp. 379-398.

Pomering, A. and Dolnicar, S. (2009). "Assessing the prerequisite of successful CSR implementation", Journal of Business Ethics, Vol. 85, pp. 285-301. 
Puncheva-Michelotti, P., Michelotti, M. and Gahan, P. (2010), "The relationship between individuals' recognition of human rights and responses to socially responsible companies", Journal of Business Ethics, Vol. 93 No. 4, pp. 583-605.

Scott, W.R. (2014), Institutions and Organizations (4th ed.), Sage, Thousand Oaks.

Skarmeas, D. and Leonidou, C.N. (2013), "When consumers doubt, watch out! the role of CSR skepticism”, Journal of Business Research, Vol. 66, pp. 1831-1838.

Skinner, C., Mersham, G.M. and Valin, J. (2003), "Global protocol on ethics in public relations", Journal of Communication Management, Vol. 8 No. 1, pp. 13-28.

Sriramesh, K. and Vercic, D. (2009), The Global Public Relations Handbook, Routledge, New York.

Suchman, M.C. (1995), "Managing legitimacy: strategic and institutional approaches", Academy of Management Review, Vol. 20 No. 3, pp. 571-610.

Taylor, J.R. and Robichaud, D. (2004), "Finding the organization in the communication", Organization, Vol. 11 No. 3, pp. 395-413.

Waddock, S.A., Bodwell, C. and Graves, S.B. (2002), "Responsibility: the new business imperative", Academy of Management Executive, Vol. 16 No. 2, pp. 132-148.

Weick, K.E. (1979), The Social Psychology of Organizing, McGraw-Hill, New York.

Weick, K.E. (2001), Making Sense of the Organization, Blackwell Publishers, Malden.

Weick, K.E. (2009), Making Sense of the Organization. Vol. 2, Wiley, Chichester.

Weyzig, F. (2006), "Local and global dimensions of corporate social responsibility in Mexico", The Journal of Corporate Citizenship, Vol. 24, pp. 69-81.

Whelan, G. (2007), "Corporate social responsibility in Asia", in May, S., et al. (Eds.), The Debate over Corporate Social Responsibility, Oxford University Press, New York, pp. 105-118.

Wilcox, D.L., Ault, P.H. and Agee, W.K. (2003), Public Relations Strategies and Tactics, Harper \& Row, New York.

Wilensky, H.L. (1967), Organizational Intelligence, Basic Books, New York.

Winzenried, S. and Adhitya, F. (2014), "Challenging times ahead for the Indonesian mining sector", available at: http://www.thejakartapost.com/news/2014/01/27/challenging-times-aheadindonesian-mining-sector.html (accessed 7 July 2016).

Yakovleva, N. (2005), Corporate Social Responsibility in the Mining Industries, Ashgate Publishing Limited, Hampshire.

Yin, R.K. (2009), Case Study Research (4th ed.), Sage, Thousand Oaks.

Zhao, Y., et al. (2014), "Corporate social responsibility assessment: a multi dimensional and dynamic perspective", Mining Technology, Vol. 123 No. 4, pp. 230-239. 
Appendix

Table 1. Five Key Roles of CSR and PR

\begin{tabular}{|c|c|c|}
\hline No. & Role & Description \\
\hline \multirow[t]{2}{*}{1.} & $\begin{array}{l}\text { Relationship building } \\
\text { [CSR and PR] }\end{array}$ & $\begin{array}{l}\text { Building and maintaining good relationships with public, especially the } \\
\text { local community. } \\
\text { - "CSR is an instrument to make an interaction. When the } \\
\text { community is there, while the company is here, CSR programs } \\
\text { become tools to build relationships ... If we can perform CSR } \\
\text { well; it means that we also perform a good PR practice." [B-01] } \\
\text { - "When we implement CSR, at the same time we carry out PR } \\
\text { functions. We practice PR when we conduct a community } \\
\text { development program." [C-06] }\end{array}$ \\
\hline & & $\begin{array}{l}\text { Reducing conflicts with communities. } \\
\text { - "Community development programs aim to decrease the gap } \\
\text { between the company and communities." [A-04] } \\
\text { - "If CSR programs are well managed, social conflicts will } \\
\text { decrease." [A-10] }\end{array}$ \\
\hline 2. & $\begin{array}{l}\text { Image building [CSR } \\
\text { and PR] }\end{array}$ & $\begin{array}{l}\text { Creating positive corporate image. } \\
\text { - "PR and CSR are about image building ... The more often we } \\
\text { interact with communities, the better our corporate image will } \\
\text { be." [A-05] }\end{array}$ \\
\hline 3. & Facilitator $[\mathrm{PR}]$ & $\begin{array}{l}\text { Ensuring a smooth implementation of CSR programs by gaining strong } \\
\text { support from local public figures (e.g., religious leaders, former and } \\
\text { current village heads). } \\
\text { - "In general the main responsibility of the Community Relations } \\
\text { Department (those responsible with performing PR functions) is } \\
\text { to ensure that there will be no disturbances from the community } \\
\text { towards the mining operation." [B-08] }\end{array}$ \\
\hline 4. & $\begin{array}{l}\text { Information } \\
\text { dissemination [PR] }\end{array}$ & $\begin{array}{l}\text { Disseminating information about community development programs to } \\
\text { the society and other stakeholders. } \\
\text { - "PR jobs mostly focus on what the company has undertaken for } \\
\text { its community." [A-08] } \\
\text { - "We communicate to the public what the company has done to } \\
\text { develop the community. We socialize our community } \\
\text { development programs among the community. Thus, they will be } \\
\text { able to accept us as a good company." [C-01] }\end{array}$ \\
\hline 5. & Education [PR] & $\begin{array}{l}\text { Educating the local communities about the mining industry and the } \\
\text { danger of illegal mining practices. } \\
\text { - "Many community members are still uneducated or had a low } \\
\text { education background.... Mining industry is a new industry for } \\
\text { them. Thus, the company needs to educate them." [C-03] }\end{array}$ \\
\hline
\end{tabular}

